\title{
Climate sensitivity of Storglaciären, Sweden: an intercomparison of mass-balance models using ERA-40 re-analysis and regional climate model data
}

\author{
Regine HOCK, ${ }^{1,2}$ Valentina RADIĆ, ${ }^{2,3}$ Mattias DE WOUL ${ }^{3}$ \\ ${ }^{1}$ Department of Earth Sciences, Uppsala University, Villavägen 16, SE-752 36 Uppsala, Sweden \\ E-mail: regine.hock@geo.uu.se \\ ${ }^{2}$ Geophysical Institute, University of Alaska, 903 Koyukuk Drive, PO Box 757320, Fairbanks, AK 99775-7320, USA \\ ${ }^{3}$ Department of Physical Geography and Quaternary Geology, Stockholm University, SE-106 91 Stockholm, Sweden
}

\begin{abstract}
Estimates of glacier contributions to future sea-level rise are often computed from massbalance sensitivities derived for a set of representative glaciers. Our purpose is to investigate how mass-balance projections and sensitivities vary when using different approaches to compute the glacier mass balance. We choose Storglaciären, Sweden, as a test site and apply five different models including temperature-index and energy-balance approaches further varying in spatial discretization. The models are calibrated using daily European Centre for Medium-Range Weather Forecasts re-analysis (ERA-40) data. We compute static mass-balance sensitivities and cumulative mass balances until 2100 based on daily temperatures predicted by a regional climate model. Net mass-balance sensitivities to $\mathrm{a}+1 \mathrm{~K}$ perturbation and a $10 \%$ increase in precipitation spanned from -0.41 to -0.61 and from 0.19 to $0.22 \mathrm{~m} \mathrm{a}^{-1}$, respectively. The cumulative mass balance for the period 2002-2100 in response to the climate-model predicted temperature changes varied between -81 and $-92 \mathrm{~m}$ for four models, but was $-121 \mathrm{~m}$ for the fully distributed detailed energy-balance model. This indicates that mass losses may be underestimated if temperature-index methods are used instead of detailed energy-balance approaches that account for the effects of temperature changes on all energy-balance components individually. Our results suggest that future glacier predictions are sensitive to the choice of the mass-balance model broadening the spectrum in uncertainties.
\end{abstract}

\section{INTRODUCTION}

Mass-balance modelling is a crucial step in modelling the response of glaciers to future climate change and their contribution to future sea-level rise. Such models generally fall into two categories: energy-balance (Hock, 2005) and empirical temperature-index models (Hock, 2003). The former are physically based, estimating melt as the residual in the energy-balance equation, but they require detailed data input. Conversely, temperature-index models have low data requirements, but they lack a rigorous physical basis. It also remains unclear as to how the empirical relationship between air temperature and melt holds under different climate conditions. Both principal approaches have been used as the basis for estimating mass-balance sensitivities and the contributions of glacier decline to future sea-level rise (e.g. de Woul and Hock, 2005; Oerlemans and others, 2005; Raper and Braithwaite, 2006), but a fundamental question is how far results are affected by the choice of the mass-balance model under otherwise identical conditions.

The purpose of this study is a model intercomparison in order to investigate the sensitivity of mass-balance projections to the choice of the mass-balance model. We apply five different mass-balance models of varying complexity to Storglaciären, a well-investigated glacier in northern Sweden $\left(67^{\circ} 55^{\prime} \mathrm{N}, 18^{\circ} 35^{\prime} \mathrm{E}\right)$, forcing the models by daily European Centre for Medium-Range Weather Forecasts re-analysis (ERA-40) data. The calibrated models are then used to compute the static mass-balance sensitivities to a $1 \mathrm{~K}$ warming and a $10 \%$ precipitation increase, and to compute the cumulative mass-balance evolution until 2100 based on downscaled temperature output from a regional climate model.

\section{DATA}

\section{Mass balance}

Storglaciären has the longest detailed and continuous massbalance record in the world (Holmlund and others, 2005) including separate winter and summer mass balances. The glacier's area has remained roughly constant for the last 30 years $\left(\sim 3.1 \mathrm{~km}^{2}\right)$. We use the recalculated and updated mass-balance series by Hulth (2006 and unpublished data). Mean winter, summer and net mass balances over the 21 year calibration period (1981-2001) are 1.62, -1.54 and $0.08 \mathrm{~m} \mathrm{a}^{-1}$ w.e., respectively.

\section{ERA-40 re-analysis}

All models were calibrated using daily ERA-40 re-analysis data (Simmons and Gibson, 2000) using the data for the roughly $50 \times 50 \mathrm{~km}$ gridcell containing the glacier. ERA-40 data comprise a dynamically consistent three-dimensional gridded dataset that is derived from a numerical weatherforecast model combined with meteorological observations and data from satellites for the period mid-1957 to mid2002. We restrict our model calibration to the mass-balance years 1980/81 to 2000/01 since the accuracy of ERA-40 data improved from 1979 due to inclusion of satellite observations in the analysis (Simmons and others, 2004).

We retrieved daily data of $2 \mathrm{~m}$ air temperature and relative humidity, precipitation, $10 \mathrm{~m}$ wind speed and global radiation (shortwave incoming radiation). Radić and Hock (2006) compared ERA-40 temperature and precipitation data with observations in the Storglaciären region and found generally good correlation; in particular, interannual variability, 
Table 1. Tuned model parameters for five mass-balance models, coefficients of determination $\left(r^{2}\right)$ for correlation between modelled and measured area-averaged winter $\left(b_{\mathrm{w}}\right)$, summer $\left(b_{\mathrm{s}}\right)$ and net $\left(b_{\mathrm{n}}\right)$ mass balances, static mass-balance sensitivities (MBS) to a $1 \mathrm{~K}$ temperature and a $10 \%$ precipitation increase, and cumulative mass balances $\left(\mathrm{Cum} b_{\mathrm{n}}\right)$ until the year $2100 . T, P, G, \mathrm{RH}$ and $u$ are air temperature $\left({ }^{\circ} \mathrm{C}\right)$, precipitation $\left(\mathrm{mm} \mathrm{d}^{-1}\right)$, global radiation $\left(\mathrm{W} \mathrm{m}^{-2}\right)$, relative humidity $(\%)$ and wind speed $\left(\mathrm{m} \mathrm{s}^{-1}\right)$, respectively. $\Gamma_{\text {ERA }}$ is the lapse rate $\left(\mathrm{K}(100 \mathrm{~m})^{-1}\right)$ to correct for the bias between ERA-40 air temperatures and near-surface temperatures at equilibrium-line altitude (1460 ma.s.l.). $\Gamma_{\mid}$is the lapse rate $\left(\mathrm{K}(100 \mathrm{~m})^{-1}\right)$ to extrapolate the downscaled ERA-40 temperatures across the glacier. $T 0_{r / s}$ is the threshold temperature $\left({ }^{\circ} \mathrm{C}\right)$ for discriminating snow and rainfall. $\mathrm{MF}\left(\mathrm{mm} \mathrm{d}^{-1} \mathrm{~K}^{-1}\right)$ and $r_{\text {snow/ice }}\left(\mathrm{mm} \mathrm{m}^{-2} \mathrm{~W}^{-1} \mathrm{~d}^{-1} \mathrm{~K}^{-1}\right)$ are melt and radiation parameters in Equation (3); $c_{0}\left(\mathrm{~W} \mathrm{~m}^{-2} \mathrm{~d}^{-1}\right)$ and $c_{1}\left(\mathrm{~W} \mathrm{~m}^{-2} \mathrm{~d}^{-1} \mathrm{~K}^{-1}\right)$ are parameters in Equation (4). PCF is the precipitation correction factor $(\%)$, PG is the precipitation gradient (\% per $100 \mathrm{~m}$ elevation increase), $\alpha_{\mathrm{s}}, \alpha_{\mathrm{f}}, \alpha_{\mathrm{i}}$ are albedo for snow, firn and ice surfaces, respectively, and $z_{0}$ is roughness length for wind $(\mathrm{mm})$

\begin{tabular}{|c|c|c|c|c|c|c|c|c|c|}
\hline \multirow[t]{2}{*}{ Model } & \multirow{2}{*}{$\begin{array}{l}\text { Type, spatial } \\
\text { discretization }\end{array}$} & \multirow[t]{2}{*}{ Input data } & \multirow{2}{*}{$\begin{array}{l}\text { Tuned model } \\
\text { parameters }\end{array}$} & \multicolumn{3}{|c|}{$r^{2}$} & \multicolumn{2}{|c|}{ MBS } & \multirow{2}{*}{$\begin{array}{c}\text { Cum } b_{\mathrm{n}} \\
\mathrm{m}\end{array}$} \\
\hline & & & & $b_{\mathrm{w}}$ & $b_{\mathrm{s}}$ & $b_{\mathrm{n}}$ & $\begin{array}{l}+1 \mathrm{~K} \\
\mathrm{ma}^{-1}\end{array}$ & $\begin{array}{l}+10 \% \\
\mathrm{ma}^{-1}\end{array}$ & \\
\hline 1 & $\begin{array}{c}\text { T-index } \\
\text { 0-dimensional }\end{array}$ & $T, P$ & $\begin{array}{c}\Gamma_{\mathrm{ERA}}=-0.75 \\
T 0_{\mathrm{r} / \mathrm{s}}=0.7\end{array}$ & 0.76 & 0.88 & 0.79 & -0.49 & 0.19 & -81 \\
\hline 2 & $\begin{array}{c}\text { T-index } \\
\text { Elevation bands }\end{array}$ & $T, P$ & $\begin{array}{c}\Gamma_{\mathrm{ERA}}=-0.62 * \\
T 0_{\mathrm{r} / \mathrm{s}}=0.3\end{array}$ & 0.78 & 0.88 & 0.82 & -0.53 & 0.19 & -87 \\
\hline 3 & $\begin{array}{c}\text { T-index } \\
\text { Grid-based }\end{array}$ & $T, P$ & $\begin{array}{c}\Gamma_{\mathrm{ERA}}=-0.69, \Gamma_{\mathrm{I}}=-0.55 \\
\mathrm{MF}=1.4 \\
r_{\text {snow }}=0.012 \\
r_{\text {ice }}=0.0168 \\
\mathrm{PCF}=38 \\
\mathrm{PG}=-40(<1280 \mathrm{~m} \text { a.s.l }) \\
=63(\geq 1280 \mathrm{~m} \text { a.s.l }) \\
T 0_{\mathrm{r} / \mathrm{s}}=1.5\end{array}$ & 0.75 & 0.87 & 0.77 & -0.58 & 0.22 & -92 \\
\hline 4 & $\begin{array}{l}\text { Energy balance } \\
\text { Elevation bands }\end{array}$ & $\begin{array}{c}T, P \\
G\end{array}$ & $\begin{aligned} \Gamma_{\text {ERA }}= & -0.58, \Gamma_{1}=-0.64 \\
C_{0}= & -26.4 c_{1}=3.6 \\
& P C F=38 \\
P G= & -27(<1280 \text { m a.s.l }) \\
= & 62(\geq 1280 \text { ma.s.l }) \\
& T 0_{r / s}=1.3 \\
\alpha_{\mathrm{i}}= & 0.30, \alpha_{\mathrm{f}}=0.50\end{aligned}$ & 0.78 & 0.66 & 0.68 & -0.41 & 0.20 & -86 \\
\hline 5 & $\begin{array}{l}\text { Energy balance } \\
\text { Grid-based }\end{array}$ & $\begin{array}{c}T, P \\
\mathrm{G} \\
\mathrm{RH}, \mathrm{u}\end{array}$ & $\begin{array}{c}\Gamma_{\mathrm{ERA}}, \Gamma_{1}, \mathrm{PCF}, \mathrm{PG}, T 0_{r / \mathrm{s}} \text { as model } 3 \\
\alpha_{\mathrm{i}}=0.37, \alpha_{\mathrm{f}}=0.68, \alpha_{\mathrm{s}}=0.73 \\
z_{0}=5\end{array}$ & 0.73 & 0.72 & 0.69 & -0.61 & 0.22 & -121 \\
\hline
\end{tabular}

*Average, different values for each elevation band.

which is crucial for the mass-balance modelling, is captured well. Since ERA-40 temperatures refer to the mean gridcell elevation of $623 \mathrm{~m}$ a.s.l., considerably lower than the elevation range of the glacier (1140-1730 m a.s.I.), daily ERA-40 temperatures were downscaled to the approximate average elevation of the equilibrium line (1460 m a.s.l.) according to a model-specific constant statistical temperature lapse rate ( $\Gamma_{\mathrm{ERA}}$ in Table 1 ) obtained from calibration of each of the models. It is emphasized that this lapse rate includes temperature variations with elevation, horizontal distance and model bias. Systematic biases between ERA-40 precipitation data and observations (Radić and Hock, 2006) are dealt with in different ways depending on the model type (see below). We use ERA-40 relative humidity and global radiation data unaltered, since comparison with data collected during the 1998-2002 glacio-meteorological campaign on Storglaciären (Jonsell and others, 2003) indicated a lack of systematic biases. Daily $10 \mathrm{~m}$ ERA-40 wind speed was computed as the arithmetic average of 6 hourly instantaneous values. These data show systematic underestimation compared to daily mean wind speeds measured at $2 \mathrm{~m}$ above the surface. We corrected for this difference based on linear regression between daily values of ERA-40 data and the observations in order to downscale the
$10 \mathrm{~m}$ ERA-40 data to the $2 \mathrm{~m}$ wind speeds on the glacier required as input in the energy-balance modelling.

\section{Climate scenario}

For the mass-balance projections until 2100 we use daily airtemperature data from the regional climate model RCA3 of the Rossby Centre of the Swedish Meteorological and Hydrological Institute (Kjellström and others, 2005), extracting the data for the roughly $50 \times 50 \mathrm{~km}$ gridcell closest to Storglaciären. The lateral boundaries are given by output of the general circulation model ECHAM4/OPYC3, and runs are forced by the B2 emission scenario from Houghton and others (2001). RCA3 predicts a temperature rise of $2.94 \pm$ $0.26 \mathrm{~K}$ per century. RCA3 temperature series were downscaled using 'local scaling' (Salathé, 2005) which means that the daily RCA3 data were adjusted by the averaged monthly differences over the 1981-2001 baseline period between the RCA3 and ERA-40 temperatures (Radić and Hock, 2006). By doing this, the average bias between the RCA3 and ERA-40 temperatures is corrected for.

For precipitation, relative humidity, wind speed and global radiation, we assume no future changes and simply replicate the 20 year ERA-40 data series from 1981 to 2000 to represent the conditions from 2001 to 2100 based on the 


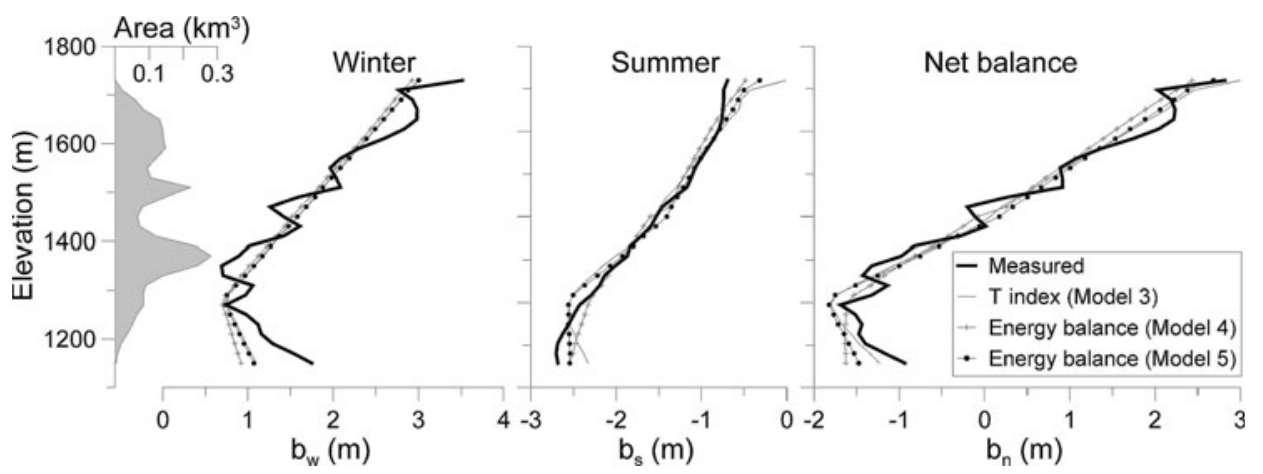

Fig. 1. Area-elevation distribution of Storglaciären (based on the 1990 map) and modelled and measured winter $\left(b_{\mathrm{w}}\right)$, summer $\left(b_{\mathrm{s}}\right)$ and net $\left(b_{\mathrm{n}}\right)$ balance profiles averaged over the period 1980/81-2000/01. The profile for model 2 coincides with the observed profile as a consequence of the regression procedure applied.

following considerations. First, in contrast to air temperature, these variables have received far less scrutiny in terms of downscaling, and future trends appear less conclusive. Second, we focus on the sensitivity of mass balance to future temperature changes only. Third, our purpose is not to provide 'real' mass-balance projections but rather to elucidate the sensitivity of results to the choice of the massbalance model.

\section{MASS-BALANCE MODELLING}

We use five mass-balance models including temperatureindex and energy-balance approaches and further differing from each other in spatial discretization (zero-dimensional, elevation bands, fully distributed (grid-based)). The models are briefly outlined below in order of increasing model sophistication, and model parameters obtained from calibration (optimization) are listed in Table 1. All models are run with daily time-step.

\section{Model 1: zero-dimensional temperature-index regression model}

We use a simple degree-day approach following de Woul and Hock (2005) and Radić and Hock (2006). Summer mass balance, $b_{\mathrm{s}}$, and winter mass balance, $b_{\mathrm{w}}$, are modelled by

$$
\begin{aligned}
& b_{\mathrm{s}}=\alpha_{\mathrm{s}} \sum_{i=t_{1}}^{t_{2}} a_{i} T_{i}+\beta_{\mathrm{s}}, \quad \begin{cases}a_{i}=1, & T_{i}>0 \\
a_{i}=0, & T_{i} \leq 0^{\prime}\end{cases} \\
& b_{\mathrm{w}}=\alpha_{\mathrm{w}} \sum_{i=t_{1}}^{t_{2}} a_{i} P_{i}+\beta_{\mathrm{w}}, \quad \begin{cases}a_{i}=1, & T_{i}<T 0_{\mathrm{r} / \mathrm{s}} \\
a_{i}=0, & T_{i} \geq T 0_{\mathrm{r} / \mathrm{s}}\end{cases}
\end{aligned}
$$

where $T_{i}$ is air temperature $\left({ }^{\circ} \mathrm{C}\right)$ downscaled by $\Gamma_{\mathrm{ERA}}$ (Table 1). The parameters $\alpha$ and $\beta$ are derived from linear regression between measured summer mass balances $\left(b_{\mathrm{s}}\right)$ and positive degree-day sums $\left(\Sigma a_{i} T_{i}\right)$ over the entire massbalance year, and between measured winter mass balances $\left(b_{\mathrm{w}}\right)$ and annual sums of daily precipitation $\left(\sum a_{i} P_{j}\right)$ with air temperatures below the threshold temperature $T 0_{\mathrm{r} / \mathrm{s}}$ which discriminates rain from snowfall.

\section{Model 2: elevation-dependent temperature-index regression model}

The model is identical to model 1 , but simulates elevationdependent mass balances. A different set of parameters $(\alpha$, $\beta$ ) is derived for each elevation band. Hence, each $20 \mathrm{~m}$ elevation band is treated as if it were an individual glacier with different optimized statistical lapse rates ( $\Gamma_{\text {ERA }}$ in Table 1).

\section{Model 3: distributed temperature-index model including potential direct solar radiation}

Melt and accumulation are computed for each gridcell of a $30 \times 30 \mathrm{~m}$ resolution elevation model according to Hock (1999). Melt, $M$ ( $\left.\mathrm{mm} \mathrm{d}^{-1}\right)$, is modelled by multiplying positive air temperatures by a melt factor, but instead of using a constant degree-day factor, the melt factor is varied for each gridcell and every time-step as a function of daily means of potential (clear-sky) direct solar radiation, thereby incorporating topographic effects on the melt distribution:

$$
\begin{array}{ll}
M=\left(\mathrm{MF}+r_{\text {snow } / \text { ice }} I_{\text {pot }}\right) T & T>0 \\
M=0 & T \leq 0
\end{array}
$$

where MF is an empirical melt factor $\left(\mathrm{mm} \mathrm{d}^{-1} \mathrm{~K}^{-1}\right)$ and $r_{\text {snow/ }}$ ice is a radiation coefficient $\left(\mathrm{mm} \mathrm{m}^{-2} \mathrm{~W}^{-1} \mathrm{~d}^{-1} \mathrm{~K}^{-1}\right)$, different for snow and ice to account for generally larger albedo over snow than ice. Firn surfaces are treated like snow. $I_{\text {pot }}$ is potential direct solar radiation at the inclined glacier surface $\left(\mathrm{W} \mathrm{m}^{-2}\right)$. $T$ is daily ERA-40 air temperature $\left({ }^{\circ} \mathrm{C}\right)$ first downscaled by $\Gamma_{\text {ERA }}$ (Table 1 ) to the approximate equilibrium-line altitude (1460 m a.s.I.) and then extrapolated to each gridcell as a function of elevation according to a local lapse rate constant in time ( $\Gamma_{1}$ in Table 1$)$. The model has successfully been applied on several glaciers (e.g. by Schneeberger and others, 2001; Flowers and Clarke, 2002; Schuler and others, 2005; de Woul and others, 2006).

Precipitation is initially adjusted by a correction factor, PCF, to account for the bias between ERA-40 data and the conditions at the glacier surface. This precipitation referring to $1280 \mathrm{ma}$ a.s.l. is then assumed to vary linearly with elevation according to two precipitation gradients, PG, different for the elevation bands below and above this elevation. We chose this elevation as breakpoint since the winter balance profiles on Storglaciären generally show an increase in winter mass balance with both increasing elevation above and decreasing elevation below this elevation (Fig. 1). The latter is due to lee effects at the steep glacier front. A temperature threshold, $\mathrm{TO}_{\mathrm{r} / \mathrm{s}}\left({ }^{\circ} \mathrm{C}\right)$, is used to discriminate snow from rain precipitation. A mixture of snow and rain is assumed in a transition zone ranging from $T 0_{\mathrm{r} / \mathrm{s}}-1 \mathrm{~K}(100 \%$ snow $)$ to $T 0_{\mathrm{r} / \mathrm{s}}+1 \mathrm{~K}(100 \%$ rain) with linear interpolation in between. 


\section{Model 4: elevation-dependent simplified energy-balance model}

We use a modified version of the model proposed by Oerlemans (2001) which parameterizes the daily mean energy available for melt, $Q_{M}\left(\mathrm{~W} \mathrm{~m}^{-2}\right)$, for each elevation band by

$$
Q_{\mathrm{M}}=(1-\alpha) Q_{\mathrm{G}}+c_{0}+c_{1} T
$$

where $\alpha$ is albedo, $Q_{\mathrm{G}}$ is global radiation $\left(\mathrm{W} \mathrm{m}^{-2}\right), T$ is air temperature $\left({ }^{\circ} \mathrm{C}\right)$ and $c_{0}$ and $c_{1}$ are parameters obtained from optimization. The term $c_{0}+c_{1} T$ represents the sum of longwave radiation balance and turbulent heat fluxes. We enhance the model by computing daily snow albedo as a function of snow depth and cumulative air temperature after last snowfall according to Brock and others (2000). Ice albedo is assumed constant. Modelling of refreezing is added according to Woodward and others (1997). The melt model may be considered as an enhanced temperatureindex model since only the shortwave radiation balance is considered, while the remaining energy components are lumped into a temperature dependence (Equation (4)). Snow accumulation is modelled as in model 3 , but no mixture of snow and rain is allowed.

\section{Model 5: distributed energy-balance model}

The model is a slightly modified version of the fully distributed surface energy-balance model by Hock and Holmgren (2005). Data input are $2 \mathrm{~m}$ air temperature, relative humidity and wind speed, as well as global radiation and precipitation. The turbulent fluxes are computed using the bulk aerodynamic approach considering atmospheric stability based on Monin-Obukhov similarity theory. Direct and diffuse radiation are extrapolated separately considering topographic effects. ERA-40 global radiation is separated into the direct and diffuse components based on an empirical relationship between the ratio of diffuse to global radiation and the ratio of global to top-of-atmosphere solar radiation. Direct radiation, $I$, is then extrapolated to the entire grid by multiplying potential direct radiation for each gridcell (computed from solar geometry, gridcell slope, aspect and topographic shading) by the ratio of actual direct radiation, $I$, derived from ERA-40 and the direct radiation if conditions were cloud-free. Diffuse radiation is extrapolated by means of a sky-view-factor relationship and by considering additional diffuse radiation reflected from adjacent slopes (see Hock and Holmgren, 2005, for further details). We modified the modelling of incoming longwave radiation, $L \downarrow$, by using the approach of Konzelmann and others (1994) which parameterizes $L \downarrow$ in terms of water vapour pressure, air temperature and cloud amount. Parameters were developed from observations during four summer seasons on Storglaciären, and cloud amount is parameterized in terms of the ratio between global radiation and top-of-atmosphere radiation (Sedlar, 2006). Snow, firn and ice albedo are assigned constant values (Table 1). Snow accumulation is computed as in model 3 .

\section{Model calibration}

All models were calibrated by tuning model parameters to yield maximum agreement between (1) modelled and observed area-averaged winter, summer and net mass balances and (2) modelled and observed winter, summer and net mass-balance profiles (not possible for model 1). For

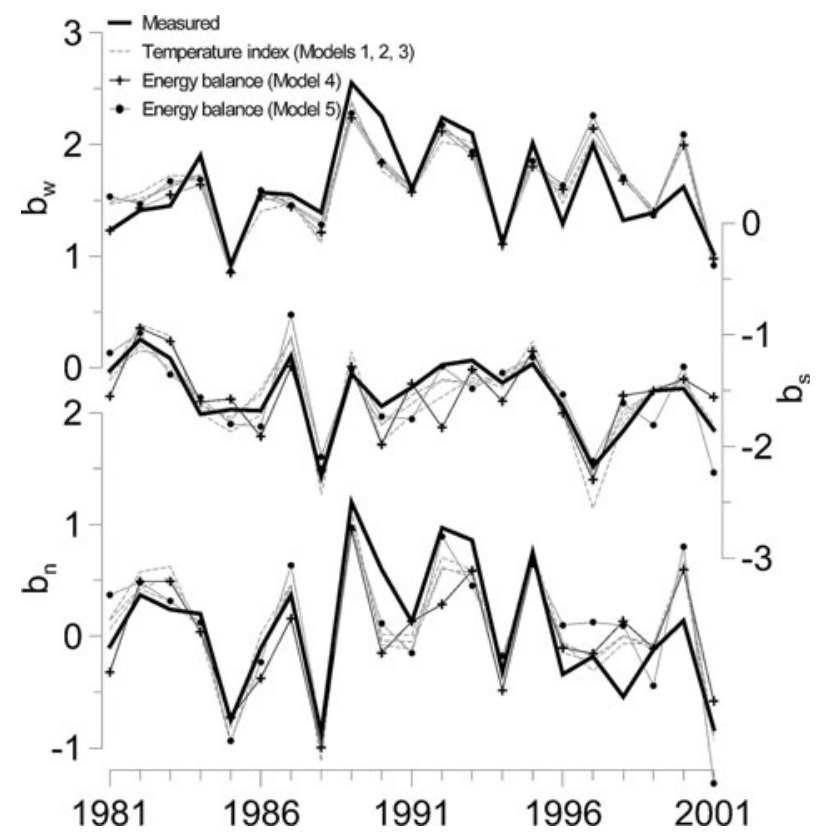

Fig. 2. Modelled and measured winter $\left(b_{\mathrm{w}}\right)$, summer $\left(b_{\mathrm{s}}\right)$ and net $\left(b_{\mathrm{n}}\right)$ mass balance for the mass-balance years 1980/81-2000/01.

models 3-5, winter balances and summer balances were integrated over the periods 15 September-14 May and 15 May-14 September, respectively. Models 1 and 2 do not require a fixed date for the winter/summer transition (Equations (1) and (2)). A combination of manual optimization and the global optimization algorithm according to Vrugt and others (2003) was applied for parameter tuning in order to derive the best-fit parameter sets. The set of model parameters for each model and their optimized values are summarized in Table 1.

\section{RESULTS AND DISCUSSION Model performance}

It was possible to tune all models so that measured massbalance profiles were reasonably well reproduced (Fig. 1). Winter mass-balance time series (Fig. 2) were modelled well by all models $\left(r^{2}=0.73-0.78\right.$; Table 1$)$, indicating that ERA40 captures interannual precipitation variability sufficiently well to be used in mass-balance modelling. Correlation statistics (Table 1) show that all temperature-index models performed considerably better $\left(r^{2}=0.87-0.88\right)$ with respect to reproducing measured summer balances than the energybalance models $\left(r^{2}=0.66-0.72\right)$. This confirms that air temperature alone is a good predictor for melt (Ohmura, 2001), and interannual temperature variability in this region is well reproduced by the ERA-40 re-analysis. The lower performance of the energy-balance models (Table 1; Fig. 2) may be attributed to the inability of the ERA-40 radiation, humidity and wind-speed data to represent the variability at Storglaciären. In contrast to air temperature, the available ERA-40 global radiation and humidity data are directly taken from the forecasts, and not re-analyzed, and thus not adjusted to observations (Simmons and Gibson, 2000). In addition, model 4 strongly parameterizes the energy-balance components and also neglects any topographic effects on the amount of global radiation in each elevation band, and hence may be oversimplified. 
Table 2. Static mass-balance sensitivities to a $1 \mathrm{~K}$ warming and a $10 \%$ increase in precipitation reported in previous studies for Storglaciären

\begin{tabular}{lcc}
\hline Study & $+1 \mathrm{~K}$ & $+10 \%$ \\
& $\mathrm{~m} \mathrm{a}^{-1}$ & $\mathrm{~m} \mathrm{a}^{-1}$ \\
\hline Oerlemans and others (1998) & -0.70 & - \\
Braithwaite and Zhang (1999) & -0.64 & - \\
Nesje and others (2000) & -0.88 & 0.14 \\
Braithwaite and others (2002) & -0.56 & 0.18 \\
de Woul and Hock (2005) & -0.46 & 0.15 \\
Rasmussen and Conway (2005) & -0.38 & 0.13 \\
\hline
\end{tabular}

\section{Mass-balance sensitivities}

Static mass-balance sensitivities in response to a hypothetical $1 \mathrm{~K}$ warming range from -0.41 to $-0.61 \mathrm{~m} \mathrm{a}^{-1}$ (Table 1). The lowest and highest values are obtained by the energybalance models. The sensitivities in response to a $10 \%$ precipitation increase vary between 0.19 and $0.22 \mathrm{~m} \mathrm{a}^{-1}$. In agreement with previous studies (Table 2), on average, the assumed precipitation increase only partially $(36-49 \%)$ offsets the effects of a $1 \mathrm{~K}$ warming.

The range reported in previous studies for a $1 \mathrm{~K}$ warming (Table 2) is somewhat larger $\left(-0.38\right.$ to $\left.-0.88 \mathrm{ma}^{-1}\right)$, but differences between studies, in addition to use of different mass-balance models, can arise from differences in applied datasets, calibration periods and procedures. Any differences in mass-balance sensitivities found here are entirely due to the choice of the mass-balance model since all models are forced by the same input data and calibrated by the same procedures. This poses a problem in using massbalance sensitivities for future glacier predictions. Massbalance sensitivities have widely been used to estimate the contribution of glaciers to future sea-level rise. The sensitivities derived for one or a few glaciers are assumed to be representative for glacier regions, and total mass loss is obtained from multiplying mass-balance sensitivities by total glacierized area (e.g. Oerlemans and others, 2005). Hence, an uncertainty in mass-balance sensitivities by a factor 1.5, as found in our case study, will add to the uncertainty in computed volume-change projections with the same magnitude.

\section{Cumulative mass-balance projections}

The cumulative net mass balances for the 100 year period until 2100 in response to the temperature changes predicted by the RCA3 regional climate model are shown in Figure 3 for all five models. It is emphasized that the predictions do not represent 'real' changes to be expected for Storglaciären. First, future climate changes in variables other than air temperature were neglected. Second, the glacier will decrease in size and retreat to higher elevations, which can lead to less negative mass balances as the glacier approaches a new steady state. We neglect such feedback on mass balance since we assume the glacier to remain constant in size. Hence, our mass balances are 'referencesurface' rather than 'conventional' mass balances (Elsberg and others, 2001; Harrison and others, 2005), and therefore the century-scale mass loss is over-predicted. However, our approach suffices in place of a more sophisticated scheme,

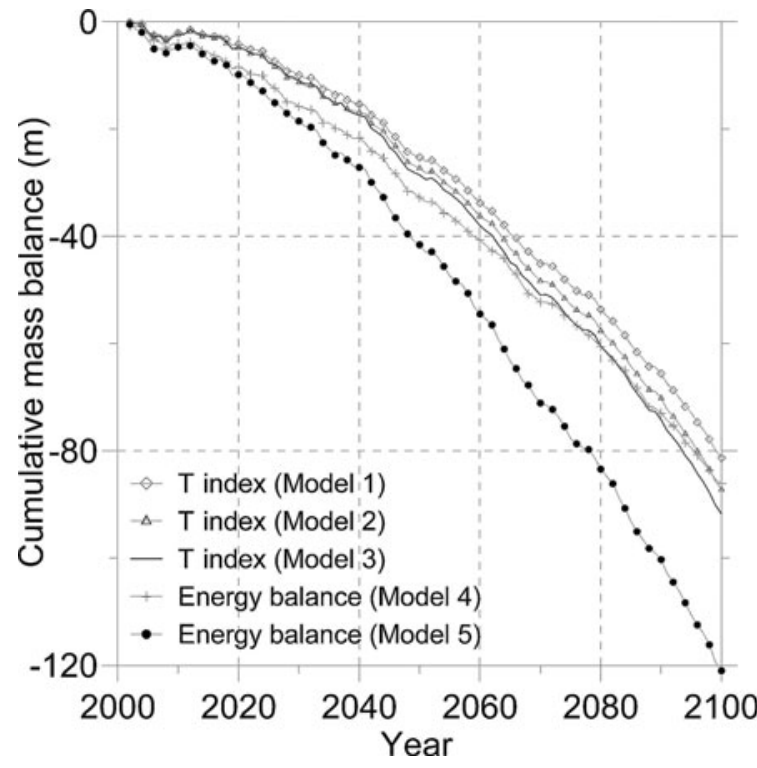

Fig. 3. Cumulative net mass balances predicted by five massbalance models for the mass-balance years 2001/02-2099/2100.

since our purpose is to investigate the sensitivity of massbalance computations solely to the choice of the massbalance model rather than to provide 'real' predictions.

Cumulative mass balances by 2100 are between -81 and $-92 \mathrm{~m}$ for models $1-4$, but $-121 \mathrm{~m}$ for model 5 . Hence, variations are within $13 \%$ of the mean for all temperatureindex models (models 1-3) and the simple elevationdependent energy-balance model (model 4), but considerably larger for the detailed energy-balance model. Our results indicate that glacier mass loss in future glacier predictions may be under-predicted when temperatureindex or highly simplified energy-balance models are used instead of detailed energy-balance models. The non-linear response of glacier mass balance to temperature changes may only be described adequately if the feedbacks on each individual component are accounted for separately according to their individual temperature dependencies.

\section{CONCLUSIONS}

We used five different mass-balance models (a zerodimensional and an elevation-dependent temperature-index regression model, a distributed temperature-index model, as well as an elevation-dependent and a fully distributed energy-balance model) to compute static mass-balance sensitivities and cumulative glacier mass loss until 2100. Model performance did not improve with increased sophistication of the model. All models produced good estimates of measured winter mass balance $\left(r^{2}=0.73-\right.$ 0.78 ) during the calibration period, but summer balances (and hence net balances) were modelled better by all temperature-index models $\left(r^{2}=0.87-0.88\right)$ than the energy-balance models $\left(r^{2}=0.66-0.72\right)$. We conclude that the elevation-dependent energy-balance model may be oversimplified and that, in contrast to air temperature and precipitation, other ERA-40 data used to force the models (such as global radiation, and in case of model 5 also wind speed and humidity) may not adequately characterize the variability of these variables in the region of Storglaciären. Further evaluation of ERA-40 global radiation, humidity and 
wind-speed data is needed in regions where corresponding long-term measurements are available in order to investigate their suitability for forcing energy-balance mass-balance models and to develop adequate downscaling methods.

Static mass-balance sensitivities to a $1 \mathrm{~K}$ warming and a $10 \%$ increase in precipitation ranged from -0.41 to $-0.61 \mathrm{~m} \mathrm{a}^{-1}$ and from 0.19 to $0.22 \mathrm{~m} \mathrm{a}^{-1}$, respectively. Hence, results differ considerably depending on the approach adopted for mass-balance modelling, indicating that the choice of the mass-balance model is a major source of uncertainty in estimation of future glacier mass loss, adding to the uncertainties in climate model predictions (Oerlemans and others, 2005; Radić and Hock, 2006) and modelling geometry changes (Radić and others, 2007). The cumulative mass balances for the 100 year period until 2100 in response to the temperature changes given by the RCA regional climate varied by $13 \%$ of the mean $(-81$ to $-92 \mathrm{~m}$ ) for four of the models, but the response of the fully distributed detailed energy-balance model was much larger $(-121 \mathrm{~m})$. This indicates that glacier mass loss in future glacier predictions may be under-predicted when temperature-index or highly simplified energy-balance models are used instead of detailed energy-balance models that account for the feedback of temperature changes on each individual energy component separately. More model intercomparisons are needed to ascertain this result.

\section{ACKNOWLEDGEMENTS}

Financial support has been provided by Formas - the Swedish Research Council for Environment, Agricultural Sciences and Spatial Planning (project No. 21.4/2003-0387) and the CE (Climate and Energy) project funded by Nordic Energy Research (NEFP). R. Hock is Royal Swedish Academy of Science Research Fellow supported by a grant from the Knut Wallenberg Foundation. We acknowledge Rossby Centrum at the Swedish Meteorological and Hydrological Institute, particularly E. Kjellström, for providing the RCA3 data, and P. Kållberg and C. Maass (ECMWF) for helping to retrieve ERA-40 data. The ERA-40 data were received from ECMWF. R. Braithwaite and an anonymous reviewer provided useful comments on the manuscript.

\section{REFERENCES}

Braithwaite, R.J. and Y. Zhang. 1999. Modelling changes in glacier mass balance that may occur as a result of climate changes. Geogr. Ann., 81A(4), 489-496.

Braithwaite, R.J., Y. Zhang and S.C.B. Raper. 2002. Temperature sensitivity of the mass balance of mountain glaciers and ice caps as a climatological characteristic. Z. Gletscherkd. Glazialgeol., 38(1), 35-61.

Brock, B.W., I.C. Willis and M.J. Sharp. 2000. Measurement and parameterization of albedo variations at Haut Glacier d'Arolla, Switzerland. J. Glaciol., 46(155), 675-688.

de Woul, M. and R. Hock. 2005. Static mass-balance sensitivity of Arctic glaciers and ice caps using a degree-day approach. Ann. Glaciol., 42, 217-224.

de Woul, M., R. Hock, M. Braun, T. Thorsteinsson, T. Jóhannesson and S. Halldórsdóttir. 2006. Firn layer impact on glacial runoff: a case study at Hofsjökull, Iceland. Hydrol. Process., 20(10), $2171-2185$.

Elsberg, D.H., W.D. Harrison, K.A. Echelmeyer and R.M. Krimmel. 2001. Quantifying the effects of climate and surface change on glacier mass balance. J. Glaciol., 47(159), 649-658.
Flowers, G.E. and G.K.C. Clarke. 2002. A multicomponent coupled model of glacier hydrology: 2. Application to Trapridge Glacier, Yukon, Canada. J. Geophys. Res., 107(B11), 2288. (10.1029/ 2001JB001122.

Harrison, W.D., D.H. Elsberg, L.H. Cox and R.S. March. 2005. Correspondence. Different mass balances for climatic and hydrologic applications. J. Glaciol., 51(172), 176.

Hock, R. 1999. A distributed temperature-index ice- and snowmelt model including potential direct solar radiation. J. Glaciol., 45(149), 101-111.

Hock, R. 2003. Temperature index melt modelling in mountain areas. J. Hydrol., 282(1-4), 104-115.

Hock, R. 2005. Glacier melt: a review on processes and their modelling. Progr. Phys. Geogr., 29(3), 362-391.

Hock, R. and B. Holmgren. 2005. A distributed surface energybalance model for complex topography and its application to Storglaciären, Sweden. J. Glaciol., 51(172), 25-36.

Holmlund, P., P. Jansson and R. Pettersson. 2005. A re-analysis of the 58 year mass-balance record of Storglaciären, Sweden. Ann. Glaciol., 42, 389-394.

Houghton, J.T. and 7 others, eds. 2001. Climate change 2001: the scientific basis. Contribution of Working Group I to the Third Assessment Report of the Intergovernmental Panel on Climate Change. Cambridge, Cambridge University Press.

Hulth, J. 2006. Ackumulationsmönster på Storglaciären 19662005. (MSc thesis, University of Stockholm.)

Jonsell, U., R. Hock and B. Holmgren. 2003. Spatial and temporal variations in albedo on Storglaciären, Sweden. J. Glaciol., 49(164), 59-68.

Kjellström, E. and 9 others. 2005. A 140-year simulation of European climate with the new version of the Rossby Centre regional atmospheric climate model (RCA3). SMHI Rep. Meteorol. Climatol. 108.

Konzelmann, T., R.S.W. van de Wal, J.W. Greuell, R. Bintanja, E.A.C. Henneken and A. Abe-Ouchi. 1994. Parameterization of global and longwave incoming radiation for the Greenland ice sheet. Global Planet. Change, 9(1-2), 143-164.

Nesje, A., Ø. Lie and S.O. Dahl. 2000. Is the North Atlantic Oscillation reflected in Scandinavian glacier mass balance records? J. Quat. Sci., 15(6), 587-601.

Oerlemans, J. 2001. Glaciers and climate change. Lisse, etc., A.A. Balkema.

Oerlemans, J. and 10 others. 1998. Modelling the response of glaciers to climate warming. Climate Dyn., 14(4), 267-274.

Oerlemans, J. and 8 others. 2005. Estimating the contribution from Arctic glaciers to sea-level change in the next 100 years. Ann. Glaciol., 42, 230-236.

Ohmura, A. 2001. Physical basis for the temperature-based meltindex method. J. Appl. Meteorol., 40(4), 753-761.

Radić, V. and R. Hock. 2006. Modeling future glacier mass balance and volume changes using ERA-40 reanalysis and climate models: sensitivity study at Storglaciären, Sweden. J. Geophys. Res., 111(F3), F03003. (10.1029/2005JF000440.)

Radić, V., R. Hock and J. Oerlemans. 2007. Volume-area scaling approach vs flowline model in glacier volume projections. Ann. Glaciol., 46 234-240.

Raper, S.C.B. and R.J. Braithwaite. 2006. Low sea level rise projections from mountain glaciers and icecaps under global warming. Nature, 439(7074), 311-313.

Rasmussen, L.A. and H. Conway. 2005. Influence of upper-air conditions on glaciers in Scandinavia. Ann. Glaciol., 42, 402-408.

Salathé, E.P. 2005. Downscaling simulations of future global climate with application to hydrologic modelling. Int. J. Climatol., 25(4), 419-436.

Schneeberger, C., O. Albrecht, H. Blatter, M. Wild and R. Hock. 2001. Modelling the response of glaciers to a doubling in atmospheric $\mathrm{CO}_{2}$ : a case study of Storglaciären. Climate Dyn., 17(11), 825-834. 
Schuler, T.V. and 6 others. 2005. Distributed mass-balance and climate sensitivity modelling of Engabreen, Norway. Ann. Glaciol., 42, 395-401.

Sedlar, J. 2006. Incoming longwave radiation parameterizations in a glacier environment: a case study on Storglaciären, Sweden. (MSc thesis, University of Stockholm.)

Simmons, A.J. and J.K. Gibson. 2000. The ERA-40 project plan. Reading, European Centre for Medium-Range Weather Forecasts. (ERA-40 Project Report Series 1.)

Simmons, A.J. and 8 others. 2004. Comparison of trends and lowfrequency variability in CRU, ERA-40, and NCEP/NCAR analyses of surface air temperature. J. Geophys. Res., 109(D24), D24115. (10.1029/2004JD005306.)

Vrugt, J.A., H.V. Gupta, W. Bouten and S. Sorooshian. 2003. A shuffled complex evolution metropolis algorithm for optimization and uncertainty assessment of hydrologic model parameters. Water Resour. Res., 39(8), 1201. (10.1029/ 2002WR001642.)

Woodward, J., M. Sharp and A. Arendt. 1997. The influence of superimposed-ice formation on the sensitivity of glacier mass balance to climate change. Ann. Glaciol., 24, 186-190. 